\title{
The different apoptotic potential of the p53 codon 72 alleles increases with age and modulates in vivo ischaemia-induced cell death
}

\author{
M Bonafék ${ }^{\star 1}$, S Salvioli ${ }^{1}$, C Barbi ${ }^{1}$, C Trapassi ${ }^{1}$, F Tocco $^{1}$, \\ G Storci ${ }^{1}$, L Invidia ${ }^{1}$, I Vannini ${ }^{1}$, M Rossi ${ }^{1}$, E Marzi ${ }^{1}$, M Mishto ${ }^{1}$, \\ M Capri ${ }^{1}$, F Olivieri ${ }^{2}$, R Antonicelli ${ }^{3}, M_{M}$ Memo $^{4}$, D Uberti ${ }^{4}$, \\ B Nacmias ${ }^{5}$, S Sorbi ${ }^{5}$, D Monti ${ }^{6}$ and C Franceschi ${ }^{1,2,7}$ \\ 1 Department of Experimental Pathology, University of Bologna, Bologna, Italy \\ 2 Department of Gerontological Research, INRCA, Ancona, Italy \\ ${ }^{3}$ Department of Cardiology, INRCA, Ancona, Italy \\ 4 Department of Biomedical Sciences and Biotechnologies, University of \\ Brescia, Brescia, Italy \\ ${ }^{5}$ Department of Neurology, University of Florence, Florence, Italy \\ 6 Department of Experimental Pathology and Oncology, University of Florence, \\ Florence, Italy \\ 7 Interdepartmental Center for studies on biophysics, bioinformatics and \\ biocomplexity 'L. Galvani' (CIG), Bologna, Italy \\ * Corresponding author: M Bonafé, Department of Experimental Pathology, \\ University of Bologna, Bologna, Italy. Tel: + 39-051-209-4739; \\ Tel: +39-051-209-4747, E-mail: macho123@alma.unibo.it
}

Received 09.10.03; revised 29.12.03; accepted 15.1.04; published online 07.5.04 Edited by V De Laurenzi

\begin{abstract}
A common arginine to proline polymorphism is harboured at codon 72 of the human p53 gene. In this investigation, we found that fibroblasts and lymphocytes isolated from arginine allele homozygote centenarians and sexagenarians ( $\mathrm{Arg}+$ ) undergo an oxidative-stress-induced apoptosis at a higher extent than cells obtained from proline allele carriers (Pro + ). At variance, the difference in apoptosis susceptibility between Arg + and Pro + is not significant when cells from 30-year-old people are studied. Further, we found that Arg + and Pro + cells from centenarians differ in the constitutive levels of p53 protein and p53/MDM2 complex, as well as in the levels of oxidative stress-induced $\mathrm{p53} / \mathrm{Bcl}-\mathrm{xL}$ complex and mitochondria-localised p53. Consistently, all these differences are less evident in cells from 30-year-old people. Finally, we investigated the in vivo functional relevance of the p53 codon 72 genotype in a group of old patients (66-99 years of age) affected by acute myocardial ischaemia, a clinical condition in which in vivo cell death occurs. We found that Arg + patients show increased levels of Troponin I and CK$M B$, two serum markers that correlate with the extent of the ischaemic damage in comparison to Pro + patients. In conclusion, these data suggest that p53 codon 72 polymorphism contributes to a genetically determined variability in apoptotic susceptibility among old people, which has a potentially relevant role in the context of an age-related pathologic condition, such as myocardial ischaemia.
\end{abstract}

\author{
Cell Death and Differentiation (2004) 11, 962-973. \\ doi:10.1038/sj.cdd. 4401415 \\ Published online 7 May 2004
}

Keywords: ageing; p53 codon 72 locus; oxidative stress; cell death; myocardial ischaemia

\begin{abstract}
Abbreviations: $<2 c$ cells, cells with hypodiploic DNA content; ACS, acute coronary syndrome; Arg + , arginine/arginine carriers; CCU, Coronary Care Unit; CK-MB, creatine kinase, MB fraction; CRP, C-reactive protein; dc, detached cells; DFs, dermal fibroblasts; dRib, 2-deoxy-D-ribose; e.s.l., equal sample loading; HDL, high-density lipoprotein; LCLs, lymphoblastoid cells lines; NQw-MI, non-Q wave myocardial infarction; p53Arg, p53 codon 72 arginine allele; p53Pro, p53 codon 72 proline allele; PBMCs, peripheral blood mononuclear cells; PI, propidium iodide; Pp53ser 15, serine 15-phosphorylated p53; Pro + , proline/proline or proline/arginine carriers; pTet-On, tetracycline inducible plasmid; pTRE, tetracycline responsive element plasmid; $Q w-$ MI, Q-wave myocardial infarction; S.D., standard deviation; S.E.M., standard error of the mean; UA, unstable angina; $\Delta \Psi^{\text {dim }}$ cells, cells with depolarised mitochondria
\end{abstract}

\section{Introduction}

In vitro cell death is mediated by a variety of mechanisms, either p53-dependent or independent, that are elicited by a wide range of stimuli, among which are stresses, like the exposure to free radicals, reducing sugars, and low oxygen tension. ${ }^{1-3}$ In vivo, at the systemic level, these same agents play a major role in the basic mechanisms of ageing and agerelated patho-physiologic processes, such as atherosclerosis. $^{4-7}$

At the genetic levels, the data recently obtained on p66Shc null mice confirmed the existence of profound ties among the mechanisms involved in cell death, ageing, and age-related diseases. Indeed, this mouse strain is characterised by a $30 \%$ extension of lifespan, ${ }^{8}$ a decrease in the levels of in vivo systemic and tissue oxidative stress and vascular apoptosis, ${ }^{9}$ and by an abrogation of oxidative stress-induced, p53dependent apoptosis. ${ }^{8-10}$ Together with other literature data, these results suggest that p53-dependent mechanisms are candidates to play a crucial role in the pathogenesis of agerelated diseases, such as atherosclerosis and myocardial dysfunction, that is, the major causes of morbidity and mortality among elderly people. ${ }^{11-14}$

In humans, the age of the donor affects the in vitro susceptibility to oxidative stress-induced apoptosis, but a wide interstudy and interindividual variability has been reported. ${ }^{15,16} \mathrm{~A}$ major uncontrolled factor in these investigations is the genetic diversity among individuals. In this regard, it is known that p53 gene harbours a common sequence 
variation, which yields an arginine to proline aminoacidic substitution at codon 72. When transfected in p53-null cells, the two alleles differ in the capacity to modulate apoptosis, to be targeted to the mitochondria, to be degraded by the proteasome, and to bind MDM2. ${ }^{17-20}$

Here we investigated the relationship between the susceptibility to undergo apoptosis and p53 codon 72 genotype in cells (blood leucocytes, dermal fibroblasts (DFs), lymphoblastoid cell lines (LCLs)) obtained from people of different ages (30-year-old, sexagenarians, and centenarians), all carefully checked for their healthy status. ${ }^{21}$ The choice of including cells from healthy centenarians is due to the fact that, at variance with healthy sexagenarians, these people de facto escaped from the detrimental effects of age-related diseases. Consequently, data obtained from their cells offer the possibility to study the mechanisms of physiological (successful) in vivo ageing, disentangling these latter from those of age-related diseases. ${ }^{21-22}$ 2-Deoxy-D-Ribose (dRib) was chosen as an oxidative stress-inducing agent. ${ }^{23,24}$ This molecule belongs to a group of reducing sugars that trigger apoptosis, generating an increase in the levels of intracellular peroxide and carbonil radicals, as well as a decrease in intracellular $\mathrm{GSH}$, all phenomena that can be abrogated by $\mathrm{N}$ Acetyl-Cysteine. ${ }^{25-28} \mathrm{dRib}$ is in fact a relevant source for in vivo oxidative stress ${ }^{29,30}$ being synthesised by thymidine phosphorylase, an enzyme whose expression is induced by hypoxia and chronic inflammation, two conditions that share in the pathogenesis of atherosclerosis and its complications. $^{31,32}$

Since we noted that the difference in in vitro apoptosis susceptibility of the p53 codon 72 genotypes was evident predominately in old people (sexagenarians and centenarians), we investigated the in vivo relevance of the phenomenon in old subjects. Purposely, we correlated p53 codon 72 genotype with serum Troponin I and CK-MB levels (which are specific quantitative markers for the extent of the ischaemic injury) in a group of aged patients (65-99 years of age) affected by acute coronary syndrome (ACS), a clinically relevant condition determined by ischaemic cell death of the myocardial tissue.

\section{Results}

\section{The impact of $\mathrm{p} 53$ codon 72 polymorphism on oxidative stress-induced apoptosis increases with age}

Peripheral blood mononuclear cells (PBMCs), DFs, and LCLs were obtained from subjects previously assessed for the p53 codon 72 genotype. ${ }^{33,34}$ Subjects were considered as follows: Pro + (proline/proline or proline/arginine carriers) and Arg + (arginine/arginine carriers); see Materials and methods.

To evaluate the impact of p53 codon 72 genotype on the response to $\mathrm{dRib}$, we exposed PBMCs from 20 young people, 16 aged people, and 8 centenarians to $10 \mathrm{mM}$ dRib treatment for 48 and $72 \mathrm{~h}$. The percentage of cells with hypodiploid DNA content $(<2$ c cells) was taken as an index of apoptosis, the percentage of cells with depolarised mitochondria $\left(\Delta \Psi^{\mathrm{dim}}\right.$ cells) was taken as an index of the mitochondrial involvement in dRib response. We found that in centenarians' PBMCs exposed to dRib, the percentages of $<2 \mathrm{c}$ and $\Delta \Psi^{\mathrm{dim}}$ cells were higher in Arg + than in Pro + samples (Figure 1a and b, right panels). Similarly, in dRib-treated PBMCs from aged people, we found higher percentages of $<2$ c cells, but similar percentages of $\Delta \Psi^{\mathrm{dim}}$ cells in Arg + with respect to Pro + samples (Figure 1a and b, middle panels). At variance, we found no significant difference in the percentages of $<2 c$ and $\Delta \Psi^{\text {dim }}$ cells between Arg + and Pro + in dRib-treated PBMCs from young people (Figure $1 \mathrm{a}$ and $\mathrm{b}$, left panels).

To rule out a possible tissue-specificity of the above phenomenon, we exposed DFs from eight young people, four aged people, and six centenarians to $20 \mathrm{mM}$ dRib treatment for 48 and $72 \mathrm{~h}$. As an index of cell death, the percentage of $<2 c$ cells (Figure 1c) and the number of cells detached (dc) from the plastic substrate (Figure 1d) were assessed. We found higher levels of $<2 c$ cells and dc in dRib-treated $\mathrm{Arg}+\mathrm{DFs}$ with respect to Pro + DFs from centenarians (Figure 1c and d, right panels) and aged people (Figure 1c and $\mathrm{d}$, middle panels). At variance, no difference was detected in DFs from young people (Figure 1c and d, left panels).

We then assessed the apoptotic features of DFs from young people and centenarians exposed to $20 \mathrm{mM}$ dRib for 48 and $72 \mathrm{~h}$. We found that $20 \mathrm{mM}$ dRib treatment elicited nuclear condensation in all DF cultures (Figure 2a). Arg + and Pro + DFs from young people showed similar levels of cleaved PARP $85 \mathrm{kDa}$ fragment, which was detectable only after $72 \mathrm{~h}$ of $\mathrm{dRib}$ exposure. At variance, high levels of PARP $85 \mathrm{kDa}$ fragment were detectable at both 48 and $72 \mathrm{~h}$ of dRib exposure in Arg + , but not in Pro + DFs from centenarians, being detectable in the latter only after $72 \mathrm{~h}$ of dRib exposure (Figure 2b). The levels of cleaved 20/17 kDa Caspase 3 fragments were barely detectable in dRib-exposed DFs from young subjects, while they were markedly increased in dRib-exposed DFs from centenarians (Figure 2b). However, only Arg + DFs from centenarians displayed a detectable decrease of full-length $37 \mathrm{kDa}$ caspase 3 fragment, as a consequence of dRib exposure (Figure 2b).

The assays of apoptotic features were somewhat difficult in DFs, likely because they are substrate-attached, slowly replicating cells which undergo apoptosis only after a longterm dRib exposure (48-72 h). We then performed the above measurements on LCLs established from Arg + and Pro + centenarians, which are rapidly replicating cells and undergo measurable levels of apoptosis within $24 \mathrm{~h}$ of $10 \mathrm{mM} \mathrm{dRib}$ treatment. Similar to what we had observed in DFs, we found that the percentage of $<2 c$ cells (Figure $2 c$ ), the cleavage of caspase 3 and PARP was higher in Arg + with respect to Pro + LCLs exposed to $10 \mathrm{mM}$ dRib treatment (Figure $2 \mathrm{~d}$ ). Interestingly, these differences were evident even in the absence of dRib treatment (Figure $2 \mathrm{c}$ and $\mathrm{d}$ ), suggesting that the functional difference between p53 codon 72 alleles plays a role on constitutive apoptosis. We reasoned that the evidences obtained in the above experiments were in favour of the hypothesis that a functional difference between p53 codon 72 alleles, recently described in an in vitro model employing an exogenous $\mathrm{p} 53,{ }^{17}$ is likely to play a role when endogenous p53 is activated by stimuli that induce cell death. 
a

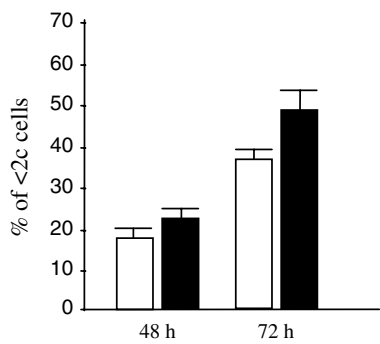

b
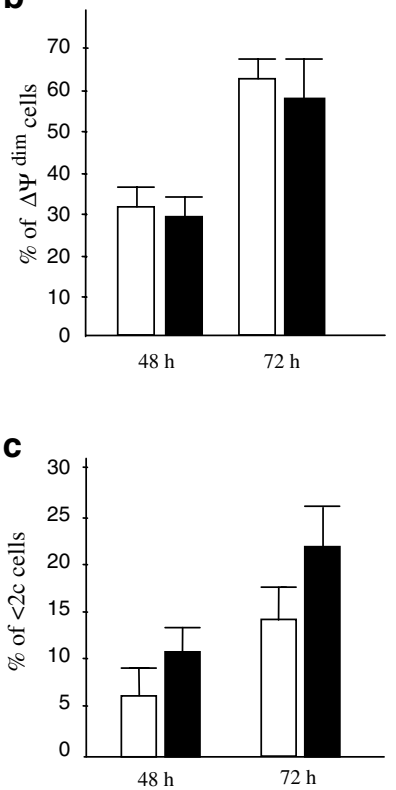

d

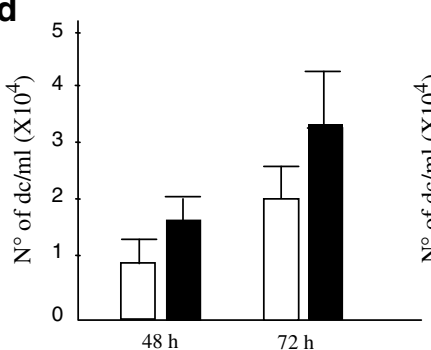

Peripheral Blood Mononuclear Cells
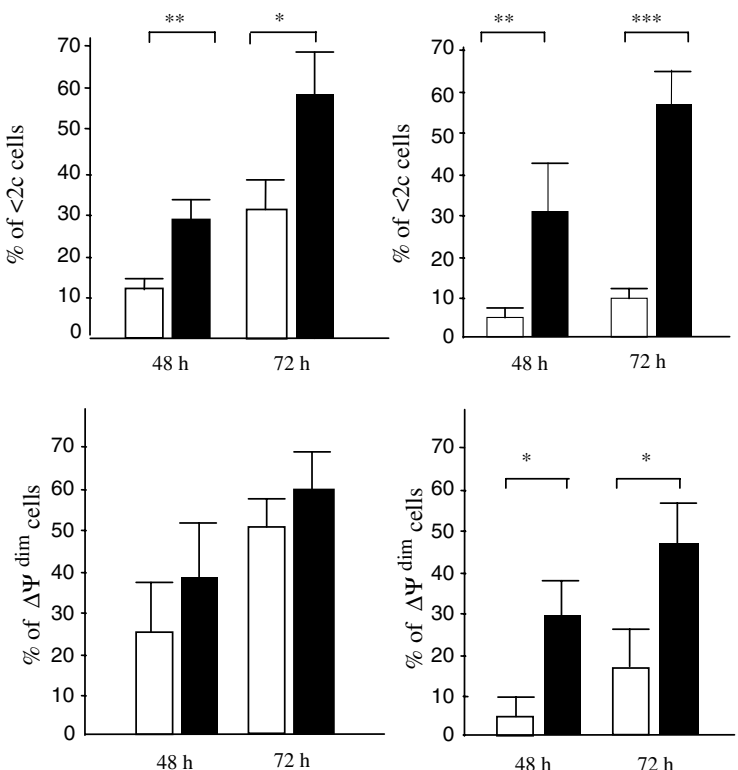

Dermal Fibroblasts
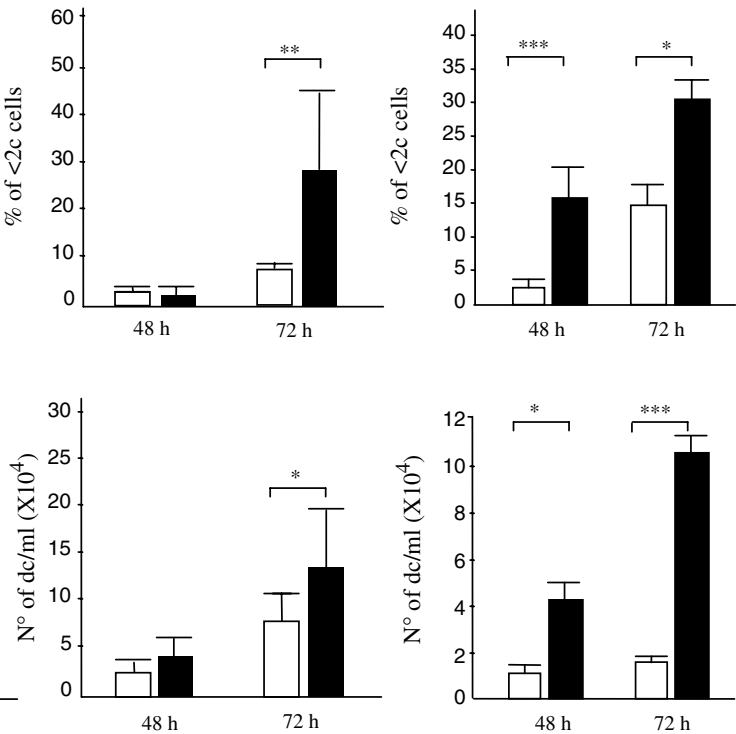

Figure 1 Susceptibility to dRib-induced apoptosis in PBMCs and DFs from subjects of different ages. PBMCs: 20 young people (eleven Pro $+v s$ nine Arg + ), 16 aged people (nine Pro + vs seven Arg + ), and eight centenarians (four Pro $+v s$ four Arg + ). DFs: eight young people (four Pro $+v s$ four Arg + ), four aged people (two Pro + vs two Arg + ), and six centenarians (three Pro $+v s$ three Arg + ). Centenarians (right panel), Aged people (middle panel), young people (left panel). (a) Percentage of PBMCs with hypodiploid DNA content ( $<2$ c cells); (b) percentage of PBMCs with depolarised mitochondria $\left(\Delta \Psi^{\text {dim }}\right.$ cells); (c) percentage of DFs with hypodiploid DNA content ( $<2$ c cells); and (d) number of detached DFs per ml of culture medium (dc). ${ }^{\star} P \leqslant 0.05 ;{ }^{* \star} P \leqslant 0.01 ;{ }^{* * *} P<0.001$, by GLM ANOVA test. Data are expressed as percentage \pm S.E.M. White bars: Pro + subjects, black bars: Arg + subjects

\section{Biochemical differences between p53 codon 72 alleles in the absence and in presence of exogenous oxidative stress}

We then assessed the activation of $p 53$, that is, the levels of total p53 and of serine 15 phosphorylated p53 (P-p53ser15) protein, in Arg + and Pro + DFs whole-cell lysates, obtained from young people and centenarians. We found that $\mathrm{dRib}$ exposure elicited an increase in total p53 and P-p53ser15 protein in DFs, which was higher in Arg + compared to Pro + cells, both in cells from young people and centenarians (Figure 3a). To assess whether the increased levels of P-p53ser15 in Arg + were entirely due to the higher levels of total p53 in these cells, we compared the amounts of P-p53ser15 in SaOs2 p53-null cells, transiently transfected with either or pCMS-p53Arg or pCMS-p53Pro expression 
a DFs Young People Pro+ Arg +

dRib 20mM 48
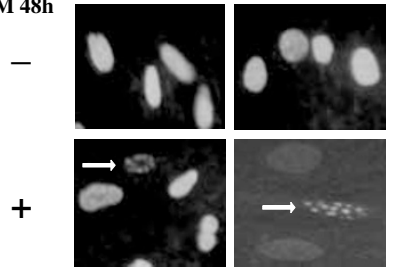

b

DFs

Young People

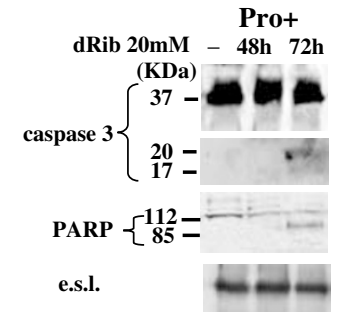

C

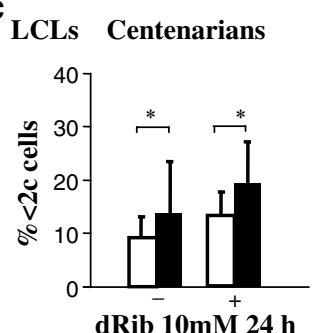

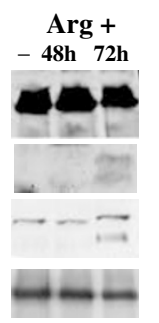

c

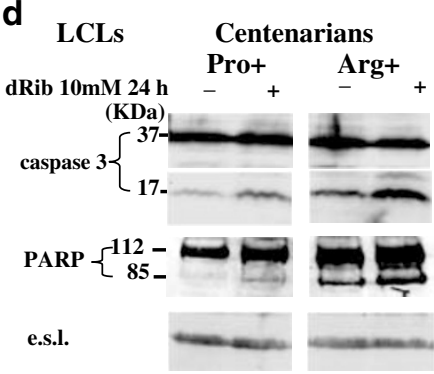

Pro+
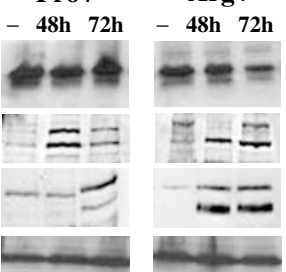

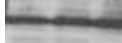

Centenarians

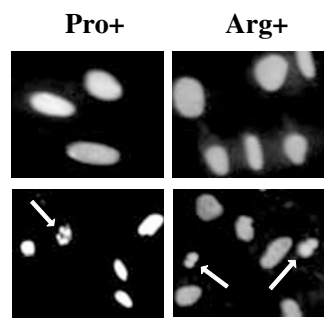

Centenarians

Figure 2 Apoptotic features of Arg + and Pro + DFs and LCLs after dRib treatment. (a) Fluorescence microscopy analysis of nuclear morphology by Hoechst 33258 staining of DFs after $48 \mathrm{~h}$ of $20 \mathrm{mM}$ dRib treatment. Arrows indicate the condensed/fragmented nuclei; (b) Western blot analysis of Caspase 3 and PARP cleavage on DFs in absence (-) or after 48 or $72 \mathrm{~h}$ of $20 \mathrm{mM}$ dRib treatment. Equal sample loading (e.s.l.) was assessed by Tubulin immunoreactivity; (c) cytofluorimetric analysis of hypodiploid DNA content ( $<2 c$ cells) on LCLs from centenarians in the absence $(-)$ or presence $(+)$ of $24 \mathrm{~h} 10 \mathrm{mM}$ dRib treatment. Data are expressed as percentage \pm S.E.M. and are referred to eight different LCLs (four Pro + vs four Arg + ). White bars: Pro + subjects, black bars: Arg + subjects. *: $P=0.044$, GLM ANOVA test; (d) Western blot analysis of Caspase 3 and PARP cleavage in LCLs from centenarians in the absence $(-)$ or presence $(+)$ of $24 \mathrm{~h} 10 \mathrm{mM}$ dRib treatment. E.s.l. was assessed by Actin immunoreactivity

vector (Figure 3b). Densitometric analysis showed that, after normalising the cell extracts for GFP protein and loading equal amounts of total p53, pCMS-p53Arg transfected cells had higher levels (about six-fold) of P-p53ser15 with respect to pCMS-p53Pro ones (Figure 3c). p53 protein activation was further demonstrated by Western blot analysis of two p53 downstream genes, namely Bax-alpha and p21WAF1 (Figure 3d). We found that both Arg + and Pro + DFs from young people and centenarians had similar levels of expression of such genes. Furthermore, p53AIP1 induction was also investigated, but no detectable levels of such gene were found (data not shown).

By comparing the levels of total p53 between Arg + and Pro + DFs, we observed that even in the absence of dRib

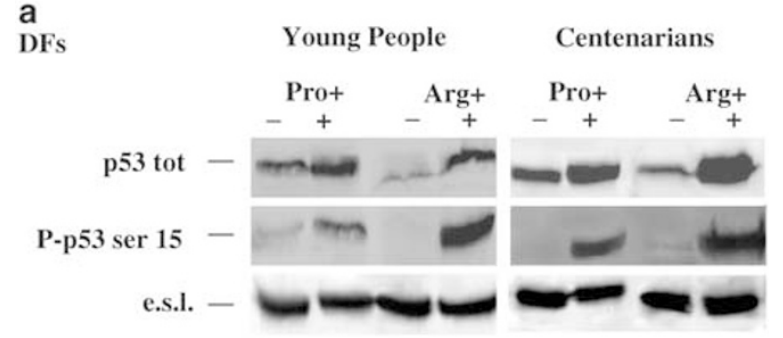

b

SaOs2 Cells

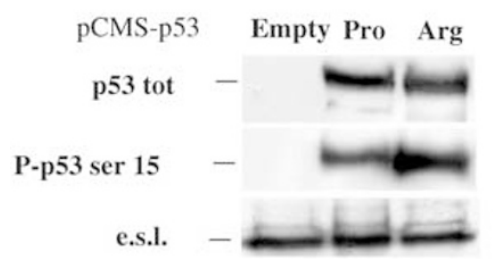

C

P-p53 ser $15 /$ Total p53 (log2 scale)

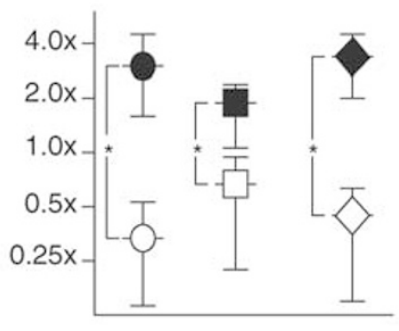

- Arg+ young people

Prot young people

- Arg+ centenarians

$\square$ Pro+ centenarians

pCMS-p53Arg SaOs2

$\diamond$ pCMS-p53Pro SaOs2

d

DFs Young People Centenarians Pro+ Arg+ Pro+ Arg+

dRib 20mM - 48h 72h - 48h 72h - 48h 72h $-48 \mathrm{~h} 72 \mathrm{~h}$

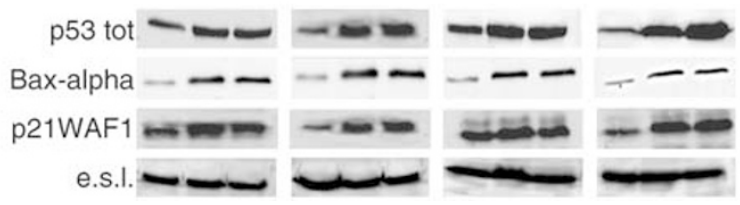

Figure 3 Western blot analysis of total p53 and Serine 15 phosphorylated p53 (P-p53 ser 15). (a) DFs from young people and centenarians, in the absence (-) or presence $(+)$ of a $48 \mathrm{~h} 20 \mathrm{mM}$ dRib treatment e.s.l. was assessed by Tubulin and (b) SaOs2 cells transiently transfected for $24 \mathrm{~h}$ with $\mathrm{pCMS}-\mathrm{p} 53 \mathrm{Arg} / \mathrm{p} 53 \mathrm{Pro}$ plasmids. E.s.I. and equal transfection efficiency were assessed by EGFP. (c) Densitometric analysis of Western blot for total p53 and P-p53 ser 15 in dRibtreated DFs $(n=3$, including the one showed in Figure $3 a)$ and pCMStransfected SaOs2 cells ( $n=3$, including the one showed in Figure $3 b)$. Ordinate $\log _{2}$ scale represents P-p53 ser 15 over Total p53 ratio. Data are expressed as fold \pm e.s.m. ${ }^{*} P<0.05$, GLM ANOVA Test. (d) Kinetic analysis of total p53 and p53 downstream genes (Bax-alpha and p21WAF1) in DFs from young people and centenarians, analysed by Western blot, after 24 and $48 \mathrm{~h}$ of $20 \mathrm{mM}$ dRib treatment. E.s.l. was assessed by Tubulin immunoreactivity 
treatment, the levels of total p53 protein were reproducibly higher in Pro + than Arg + DFs (Figure 4a). This phenomenon could not be observed in pCMS-p53Arg/p53Pro transfected SaOs2 cells, and we reasoned that this inconsistency was due to the high rate of CMV promoter-driven gene transcription. In an effort to mimic a more physiologic rate of synthesis of the p53 protein, we stably transfected SaOs2 cells with a tetracycline-inducible (pTet-On) plasmid. These cells were then transiently co-transfected with pTREp53Arg/p53Pro response plasmids, and they were exposed to low $(0.1 \mu \mathrm{g} / \mathrm{ml})$ and high $(1 \mu \mathrm{g} / \mathrm{ml})$ doses of doxycycline (Figure 4b). By means of this experimental approach, we confirmed that the levels of total p53 protein were higher in pTRE-p53Pro than in pTRE-p53Arg-transfected cells, but only in the presence of a low dose of doxycycline, which causes a low induction of gene transcription. On the contrary, in the presence of a high dose of doxycycline, the amount of p53 protein in pTRE-p53Pro/p53Arg transfected cells was similar. As the level of the p53 protein is tightly regulated by its degradation rate, we hypothesised that the above findings could be due to the previously described higher resistance of the p53Pro to the degradation by the proteasome, which yields increased steady-state levels of the p53 protein, particularly at low levels of gene transcription. ${ }^{18}$

The degradation of the $\mathrm{p} 53$ protein by the proteasome requires the physical interaction with MDM2, mediated by the polyproline domain, in which the codon 72 is harboured. ${ }^{35} \mathrm{We}$ therefore assessed the amounts of p53/MDM2 complex in DFs (in the absence of oxidative stress) as well as in pCMSp53Arg/p53Pro transiently transfected SaOs2 cells. Consistent with the data on total p53 protein levels, we found that higher amounts of MDM2 were co-immunoprecipitated together with p53 from Arg + DFs whole-cell lysates, compared to Pro + ones (Figure 4c). The difference was clearcut and reproducible in cells from centenarians, whereas it was present but less evident and consistent in cells from young people. Interestingly, we found that whole-cell lysates from centenarians contained increased levels of MDM2 with respect to those from young individuals (Figure 4c). In agreement with earlier reports, ${ }^{17}$ we found that MDM2 coimmunoprecipitated at a higher extent with p53Arg than p53Pro allele in pCMS-transfected SaOs2 cells (Figure 4d).

Independent studies recently found that MDM2 targets p53 to the mitochondria to induce apoptosis, ${ }^{17}$ and that the a

DFs Young People Centenarians

C

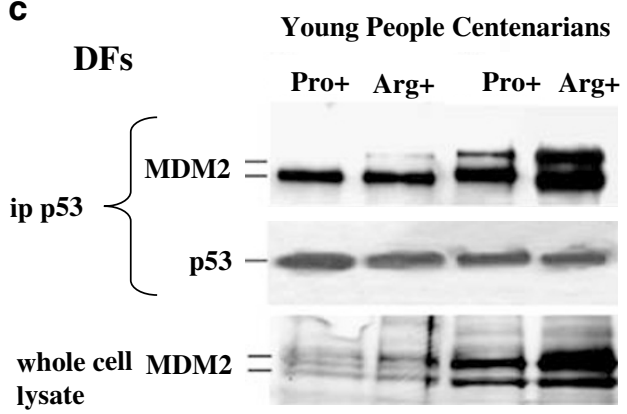

b

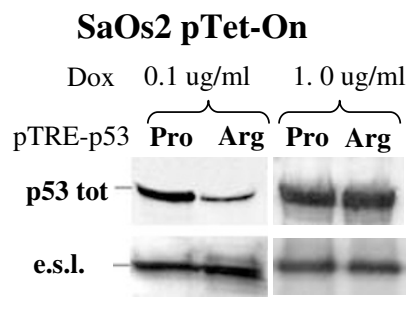

d SaOs2 Cells

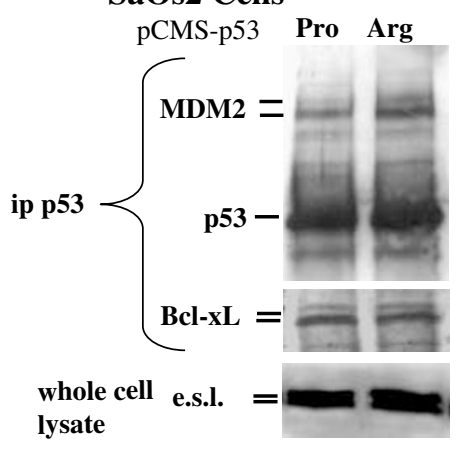

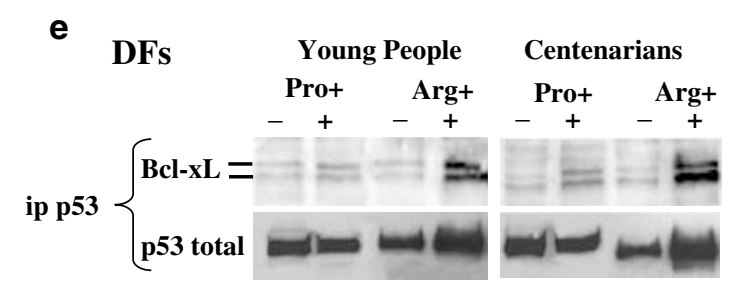

Figure 4 Biochemical differences between p53 Arg and Pro codon 72 alleles. (a and $\mathbf{b}$ ) Western blot analysis of constitutive p53: e.s.l. was assessed by Tubulin immunoreactivity. (a) DFs from young people and centenarians; (b) pTet-On SaOs2 cells transiently co-transfected with pTRE-p53Arg/p53Pro plasmids, exposed to 0.1 and $1 \mu \mathrm{g} / \mathrm{ml}$ doxycycline (Dox) for $48 \mathrm{~h}$; (c and d) Western blot analysis of immunoprecipitated p53. (c) DFs from young people and centenarians, probed with antibody for MDM2 and p53; e.s.l. was assessed by densitometric scanning of Red Ponceau staining (data not shown). (d) SaOs2 whole-cell lysate transiently transfected with pCMS-p53Arg/p53Pro plasmids, probed with antibody for MDM2, Bcl-xL and p53. e.s.l. and transfection efficiency were assessed by EGFP; (e) DFs from young people and centenarians in the absence $(-)$ or presence $(+)$ of a $48 \mathrm{~h}$ of $20 \mathrm{mM} \mathrm{dRib}$ treatment, probed with an anti-Bcl-xL. E.s.l. was assessed by densitometric scanning of Red Ponceau staining (data not shown) 
interaction of mitochondrially localised p53 with $\mathrm{Bcl}-\mathrm{xL}$ induces apoptosis. ${ }^{36}$ To test whether these phenomena could play a role in the different extent of cell death occurring in $\mathrm{Arg}+$ and Pro + DFs, we assessed the immunoprecipitated p53 for Bcl-xL immunoreactivity. We found that, after $48 \mathrm{~h}$ of $20 \mathrm{mM}$ dRib treatment, $\mathrm{p53} / \mathrm{Bcl}-\mathrm{xL}$ complex increased substantially in Arg + in DFs from young people and centenarians, whereas only a slight increase of $\mathrm{p} 53 / \mathrm{Bcl}-\mathrm{xL}$ complex was evident in Pro + DFs (Figure 4e). Interestingly, similar amounts of $\mathrm{p53} / \mathrm{Bcl}-\mathrm{xL}$ complex were present in pCMSp53Arg/p53Pro transfected SaOs2 cells (Figure 4d).

To assess whether the different mitochondrial localisation of p53 was correlated with the different apoptotic susceptibility observed in Arg + and Pro + DFs from centenarians, we assessed the localisation of endogenous p53 in the mitochondria of DFs by fluorescence microscopy. We found that, as a consequence of dRib exposure, different patterns of p53 localisation could be observed: nuclear, mitochondrial-cytoplasmic, and nuclear/mitochondrial-cytoplasmic (Figure 5 $\mathrm{a}-\mathrm{d})$. The prevalent pattern of p53 localisation in Pro + DFs was the nuclear one (Figure $5 b$ ), whereas mitochondrialcytoplasmic and nuclear/mitochondrial-cytoplasmic ones were prevalent in Arg + DFs from centenarians (Figure 5c and d). At variance, p53 positive cells in Arg + and Pro + DFs cultures from young people displayed a similar p53 localisation (Figure $5 e-f$ ). In fact, the absolute percentage of p53 positive cells in dRib-treated DF cultures was quite low (about $2-3 \%)$. We hypothesised that this finding was due to the longterm exposure time required by dRib to elicit cell death in DFs $(48 \mathrm{~h})$. In fact, the apoptogenic localisation of p53 to mitochondria occurs in a short temporal interval (1-2h) and few cells at a given time are expected to show a mitochondrially localised $\mathrm{p} 53$. $^{2}$ We then conceived that a stimulus that elicits massive cell death in few hours could enhance the difference between Arg + and Pro + DFs in p53 localisation. Purposely, we evaluated p53 localisation on DFs exposed to hydrogen peroxide $\left(\mathrm{H}_{2} \mathrm{O}_{2} 500 \mu \mathrm{M}\right)$. As expected, a larger number of DFs displayed p53 immunoreactivity (about $50 \%$ ), and consistent with the data on dRib, we found that most of the p53 positive cells showed a nuclear localisation of p53 in Pro + , and a mitochondrial-cytoplasmic p53 in Arg + DFs cultures from centenarians (Figure $5 \mathrm{~g}$ and $\mathrm{h}$ ). This difference was not evident in DFs from young people (Figure $5 i$ and $I$ ).

Remarkably, no difference on p53 mitochondrial localisation was found in pCMS-p53Arg/p53Pro transfected SaOs2 cells (data not shown), which did not differ in apoptotic rate (p53Arg vs p53Pro: $57 \pm 15$ vs $63 \pm 18$, GLM ANOVA $P=0.34$, and Dumont et al. ${ }^{17}$ ), as well as in the levels of p53/Bcl-xL complex (see Figure 4d), further suggesting that the targeting of $\mathrm{p} 53$ to $\mathrm{Bcl}-\mathrm{xL}$ and then to the mitochondria is a prerequisite for the disclosure of their different apoptotic potential.

\section{p53 codon 72 polymorphism modulates in vivo cell death}

The above data suggest that one of the causes of the difference in the apoptotic response to dRib between Arg + and Pro + DFs could be their involvement in a recently described mitochondrial-dependent, transcription-independent, apoptotic mechanism. ${ }^{17,36}$ Interestingly, a similar pathway was described in p53-transfected ventricular myocytes, ${ }^{37}$ and plays a major role in hypoxic cell death. ${ }^{2}$ As the hypoxic death of myocardial tissue is one of the most prevalent pathologic conditions in old people, we then tested the hypothesis that the myocardial cell death in vivo is modulated by $\mathrm{p} 53$ codon 72 polymorphism. Purposely, we collected DNA from 130 patients aged more than 65 years (age range 65-99, median age: $80 \pm 9$ ), affected by ACS. We then correlated p53 codon 72 polymorphism to a number of clinical and biochemical parameters. ${ }^{38}$ Multiple regression analysis showed that the serum mean levels of CK-MB and Troponin I (two markers related to the extension of the ischaemic damage) were significantly higher in Arg + patients than in Pro + ones. In particular, Arg + showed about a two-fold increase in Troponin I levels with respect to Pro + ACS patients. The other clinical, biochemical, and prognostic parameters were not significantly different between Arg + and Pro + ACS patients (Table 1).

\section{Discussion}

In this study, we found that blood leucocytes and DFs obtained from p53 codon 72 arginine allele homozygote $($ Arg +$)$ healthy sexagenarians and centenarians undergo an oxidative stress-induced apoptosis to a higher extent than proline carriers (Pro + ). At variance, we found no significant difference in the apoptosis rate between Arg + and Pro + cells obtained from young people.

So far, the increased capacity of the arginine allele (p53Arg) with respect to the proline one (p53Pro) to elicit apoptosis has been observed in p53-stably transfected cells, melanoma cell lines, ${ }^{17}$ virus-transformed cell lines, ${ }^{39}$ as well as in blood leucocytes from lung carcinoma patients, but not in blood leucocytes from healthy people ${ }^{40}$ in embryonic human fibroblasts $^{17}$ and transiently transfected cell lines (Dumont et al., ${ }^{17}$ and this investigation). These data, on one side suggest that p53 codon 72 alleles have different biochemical properties, and on the other, suggest that their functional difference, yet intrinsic, it is not always overt, being likely dependent on the intracellular environment in which it is harboured.

In an attempt to shed light on the mechanism(s) responsible for the above phenomenon, we found that, paralleling the results of apoptosis, Arg + and Pro + DFs differ in a number of features, particularly when they are obtained from centenarians. In particular, we found that, in the absence of exogenous oxidative stress, Arg + cells have lower levels of endogenous total p53 (we were able to reproduce this phenomenon by means of a p53Arg/p53Pro Tet-On system developed in SaOs2 cells), and higher amounts of p53/MDM2 complex (a phenomenon reproducible in SaOs2 p53Arg/ p53Pro transfected cells). Moreover, at least in LCLs cells in which this phenomenon is measurable, Arg + cells show higher amounts of spontaneous apoptosis, accompanied by increased levels of cleaved caspase 3 and PARP.

Interestingly, these findings are in agreement with two previous pieces of literature data, the first indicating that the 

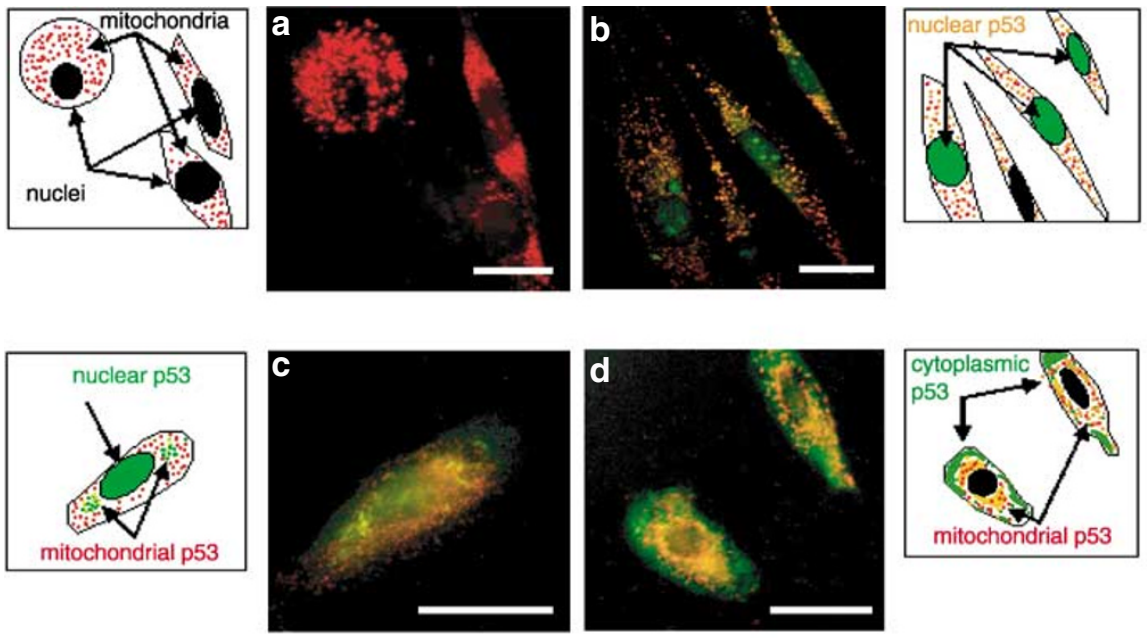
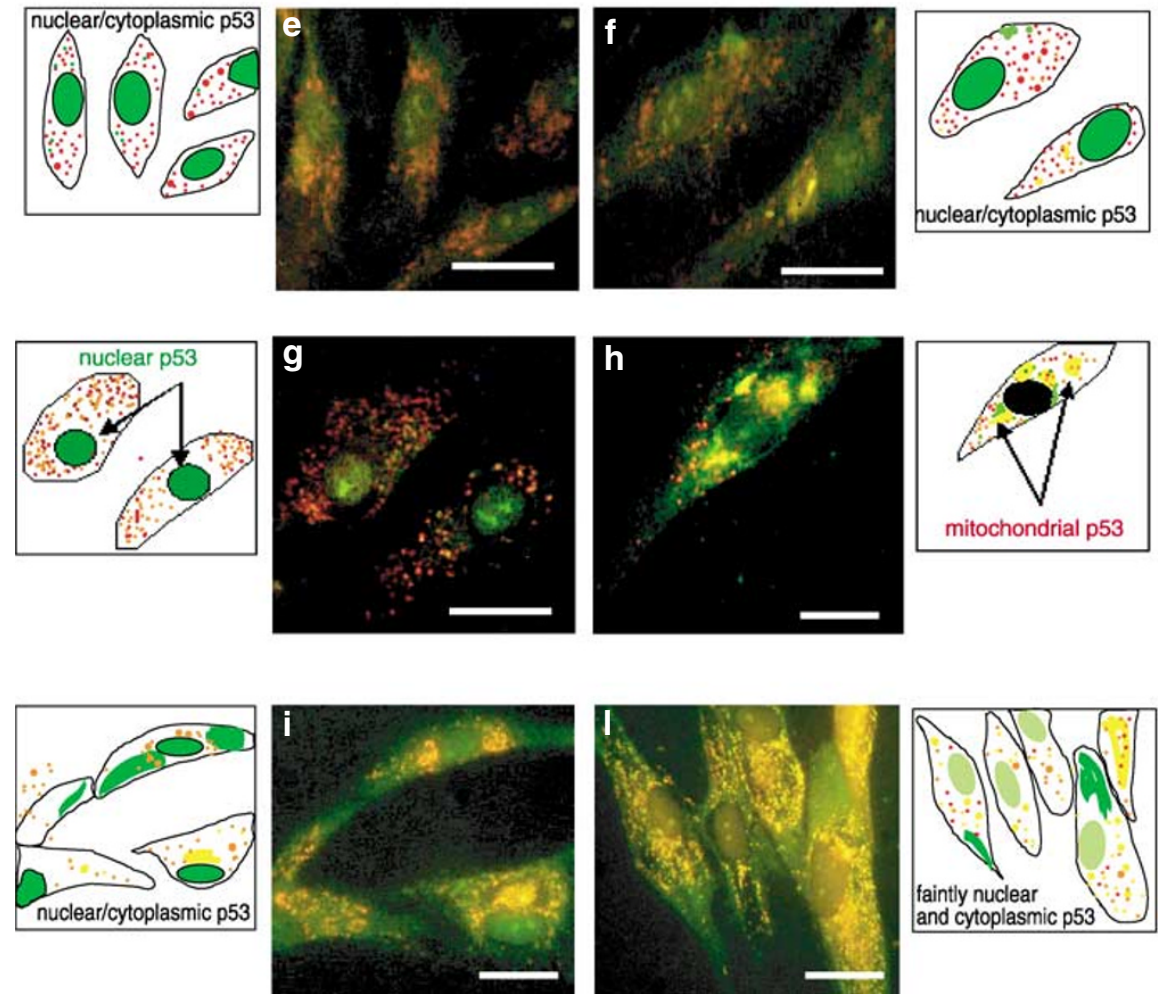

Figure 5 p53 localisation in DFs. Staining was performed by using FITC-conjugated anti-p53 mouse monoclonal antibody (green fluorescence) and the $\Delta \psi$-sensitive dye MitoTracker Red CMX-Ros ${ }^{\text {TM }}$ (red fluorescence). Digital zooming was used to better highlight p53 localisation. (a and d) Patterns of p53 expression in DFs from centenarians after $48 \mathrm{~h}$ of $20 \mathrm{mM}$ dRib treatment: (a) negative, (b) nuclear, (c) nuclear/mitochondrial, (d) cytoplasmic/mitochondrial, (e and f) representative example of a Pro + (e) and Arg + (f) DFs culture from young subjects after $48 \mathrm{~h}$ of $20 \mathrm{mM} \mathrm{dRib}$ treatment, $(\mathbf{g}-\mathbf{l})$ p53 expression in DFs from Pro $+(\mathbf{g})$ and Arg $+(\mathbf{h})$ centenarians and from Pro + (i) and Arg + (I) young people after $2 \mathrm{~h}$ of $500 \mu \mathrm{M} \mathrm{H}_{2} \mathrm{O}_{2}$ treatment. Ruler: $20 \mu \mathrm{m}$. Cartoons schematically reproduce the pictures

p53Arg allele is endowed with an enhanced capacity to bind to MDM2 protein and to elicit apoptosis in cells stably transfected with temperature-sensitive p53Arg/p53Pro alleles, ${ }^{17}$ the second pointing out that the p53Arg allele is susceptible to a higher extent to Human Papilloma Virus E6 protein-mediated proteasomal degradation in p53/E6 doubly transfected cell lines. ${ }^{19}$ Consequently, in this paper we found that both these mechanisms could play a role in the regulation of constitutive levels of endogenous p53 in DFs.
When we challenged Arg + and Pro + cells with exogenous oxidative stress, we found that, although the activation of p53 protein (increase in total p53 and P-p53ser15 protein levels) ${ }^{41}$ is higher in Arg + DFs, no difference in the activation of proapoptotic genes, such as Bax-alpha or p53AIP1, with respect to Pro + cells occurs. Rather, we found that Arg + DFs exposed to oxidative stress contain higher levels of p53 bound to the mitochondrial protein $\mathrm{Bcl}-\mathrm{xL}$, compared to Pro + DFs. ${ }^{36}$ Moreover, only in DFs from centenarians, Arg + but 


\begin{tabular}{|c|c|c|c|}
\hline & \multicolumn{3}{|c|}{ P53 codon 72 genotype } \\
\hline & $\operatorname{Arg}+(n=77)$ & Pro+ $(n=53)$ & $\boldsymbol{P}$ \\
\hline $\begin{array}{l}\text { Age (years } \pm \text { S.D.) } \\
\text { Sex }(M / F)\end{array}$ & $\begin{array}{c}80 \pm 7 \text { (range: } 65-99) \\
45 / 32\end{array}$ & $\begin{array}{c}79 \pm 7 \text { (range: } 66-95) \\
31 / 22\end{array}$ & $\begin{array}{l}0.68 \\
0.89\end{array}$ \\
\hline $\begin{array}{l}\text { Risk factors for ACS } \\
\text { Smokers } n(\%) \\
\text { Hypertension } n(\%) \\
\text { Diabetes mellitus } n(\%) \\
\text { Hypercholesterolaemia } n(\%) \\
\text { CRP }(\mathrm{mg} / \mathrm{dl} \pm \text { S.D.) } \\
\text { Vitamin } \mathrm{B}_{12}(\mathrm{pg} / \mathrm{ml} \pm \text { S.D.) } \\
\text { Folate }(\mathrm{ng} / \mathrm{ml} \pm \text { S.D.) } \\
\text { Homocysteine }(\mu \mathrm{mol} / \mathrm{l} \pm \text { S.D.) }\end{array}$ & $\begin{array}{c}12(15.6) \\
54(70.1) \\
23(29.9) \\
53(68.8) \\
4.8 \pm 5.5 \\
434 \pm 245 \\
5.8 \pm 2.6 \\
4.8 \pm 5.5\end{array}$ & $\begin{array}{c}5(9.4) \\
35(66.0) \\
17(32.1) \\
33(62.3) \\
4.1 \pm 5.6 \\
435 \pm 345 \\
5.8 \pm 2.7 \\
4.1 \pm 5.6\end{array}$ & $\begin{array}{l}0.30 \\
0.62 \\
0.78 \\
0.44 \\
0.46 \\
0.95 \\
0.85 \\
0.54\end{array}$ \\
\hline $\begin{array}{l}\text { ACS diagnosis } n(\%) \\
\text { UA } \\
\text { Qw-MI, } \\
\text { NQw-MI }\end{array}$ & $\begin{array}{l}18(23.4 \%) \\
34(44.2 \%) \\
25(32.4 \%)\end{array}$ & $\begin{array}{l}14(26.4 \%) \\
23(43.4 \%) \\
16(30.2 \%)\end{array}$ & 0.99 \\
\hline $\begin{array}{l}\text { Ischaemia markers } \\
\text { Troponin I (ng/ml } \pm \text { S.D.) } \\
\text { CK-MB (ng/ml } \pm \text { S.D.) }\end{array}$ & $\begin{array}{l}42 \pm 73 \\
84 \pm 141\end{array}$ & $\begin{array}{l}24 \pm 33 \\
78 \pm 123\end{array}$ & $\begin{array}{l}0.002^{*} \\
0.047^{\star}\end{array}$ \\
\hline
\end{tabular}

Qw-MI: Q-wave-myocardial infarction; NQw-MI: non-Q wave-myocardial infarction; UA: unstable angina; CRP: C-reactive protein. * $P$ refers to multiple regression analysis of In transformed CK-MB and Troponin I values. Age, sex, smoking habits, and risk factors for ACS were included as covariates.

not Pro + DFs show a mitochondrial localisation of p53. At variance, we found no difference in p53 intracellular localisation between Arg + and Pro + DFs from young people. Finally, again in keeping with previous data, ${ }^{17}$ we found that p53Arg and p53Pro alleles show a similar apoptotic potential in p53-transiently transfected SaOs2 cells, in which similar amounts of $\mathrm{p} 53 / \mathrm{Bcl}-\mathrm{xL}$ complex and mitochondria-localised p53 were detected (Dumont et al., ${ }^{17}$ and data not shown).

Overall, the available data on p53 codon 72 suggest that the differential targeting to the mitochondria of p53Arg and p53Pro is required to disclose their functional difference in apoptotic potential. ${ }^{17}$ Consequently, in the same cell strain or lineage, there may be permissive or nonpermissive conditions for this phenomenon. This consideration is valid both for explaining the findings obtained in cells harbouring exogenous p53 (i.e. p53 codon 72 alleles differ in their apoptotic potential in stably, but not in transient transfected SaOs2 cells; see Dumont et al. ${ }^{17}$ and this investigation), as well as endogenous p53 (p53 codon 72 alleles differ in their apoptotic potential in cells from old people and centenarians, but not young individuals). A likely candidate to play a role in this pathway is MDM2 protein, which differentially binds to the p53Arg and p53Pro alleles. In this regard, we found that MDM2 protein increases in DFs from centenarians, but at present, its causative role on the phenomenon here described remains speculative.

The in vivo relevance of such a genetically determined difference in apoptosis susceptibility between aged individuals was then examined in a group of elderly patients affected by acute ischaemic damage of the myocardial tissue, in which massive hypoxic cell death occur. We found that Arg + subjects have higher serum levels of cardiac Troponin I and $\mathrm{CK}-\mathrm{MB}$, two qualitative/quantitative markers for the extent of the ischaemic damage at the myocardial level. ${ }^{38}$ This finding can be better understood by taking into account that hypoxia-induced cell death mediates an oxidative stressinduced damage at the mitochondrial level in cardiomyocytes, ${ }^{42}$ and it induces the targeting of p53 to the mitochondrion. ${ }^{2}$ Moreover, it is known that p53 activates mitochondrialdependent death pathway in ventricular myocytes. ${ }^{37}$ Thus, it is reasonable to conceive that if $\mathrm{dRib}$ (in vitro) and hypoxia (in vivo) elicit similar pathways of cell death, a different apoptotic susceptibility between Arg + and Pro + old individuals in both situations will ensue. In this regard, although the contribution of apoptosis to ischaemic heart is less known than that of necrosis, ${ }^{43}$ there is evidence that apoptosis occurs in vivo in ischaemic myocardium, ${ }^{43}$ and that both forms of cell death share common mechanisms, especially at the mitochondrial level. ${ }^{44}$ At present, the data on our patient's series are not sufficient to disentangle the various causes of the different extents of the ischaemic damages between Arg + and Pro + , such as a different extent of the infarct size, a different extension of the atherosclerotic damage, and a different capacity of tissue repairing. All these questions are worth addressing in future studies aimed at elucidating the role of p53 in the regulation of the homeostasis of the myocardial tissue in the context of ageing and age-related diseases. The available data on mice indeed reveal an important role of p53 in the phenomena related to the ageing of cardiac tissue. ${ }^{45}$

In conclusion, in this paper we found that the difference between $\mathrm{p} 53$ codon 72 alleles in the capacity to modulate cell death is substantial only when cells from old people are assessed. This functional difference in vitro has relevance for cell death occurring in vivo as a consequence of myocardial ischaemia in aged people. These data suggest that mechanisms determining the susceptibility to in vitro apoptosis are affected by the age of the cell donor, and they can provide insights into the individual susceptibility towards major agerelated diseases, such as cardiovascular diseases. 


\section{Materials and Methods}

\section{Cells from healthy subjects with known p53 codon 72 genotype}

PBMCs, DFs, and EBV-transformed B cell lines (LCLs) were obtained from subjects previously assessed for the $p 53$ codon 72 genotype. ${ }^{33}$ Namely, 28 healthy young people (aged $30 \pm 3$ years), 20 healthy aged people (aged $69 \pm 1$ years) selected from a group of actively exercising aged people, in a good physical performance status, 22 healthy centenarians, categorised ' $A$ ' for their healthy status, as previously described. ${ }^{21,22}$ All the subjects were devoid of any clinical or biochemical abnormalities at the moment of blood collection or skin biopsy. As the p53 codon 72 proline/proline genotype is quite rare in the Italian population (about $8-10 \%),{ }^{33}$ and that the proline allele is likely to exert a dominant effect on the arginine one (Wu et al., ${ }^{39}$ Biros et al. ${ }^{40}$ and preliminary data, data not shown), two groups of subjects were considered for this study: Pro + (proline/proline and proline/arginine genotypes) and Arg + (arginine/arginine genotype) subjects. In detail, PBMCs were separated by discontinuous gradient centrifugation from the whole blood of 20 young people (mean age: $30 \pm 3$ years): 11 Pro + (one proline/proline and 10 proline/arginine) and nine Arg + subjects; 16 aged people (mean age: $69 \pm 1$ years): nine Pro + (one proline/proline and eight proline/arginine) and seven Arg + subjects; eight centenarians (mean age: $101 \pm 1$ years): four Pro + (four proline/arginine) and four Arg + subjects. PBMCs were cultured in RPMI 1640 medium supplemented with $10 \%$ FCS and 2 mM Lglutamine. DFs long-term cultures were established from eight young people (mean age: $28 \pm 6$ years): four Pro + (two proline/proline and two arginine/proline) and four Arg + subjects; four aged people (mean age: $60 \pm 3$ years): two Pro + (two arginine/proline) and two Arg + ; six centenarians (mean age: $101 \pm 1$ years): three Pro + (two proline/proline and one proline/arginine) and three Arg + subjects. DFs were cultured in DMEM supplemented with $10 \%$ FCS. DFs from the 6th to the 14th passage were used for all the experiments. A negligible percentage of $\beta$ galactosidase positive cells were present in the DFs cultures assayed (data not shown). LCLs were established according to standard procedures from eight centenarians: four Pro + (two proline/proline and two proline/arginine genotype) and four Arg + subjects. Cells were cultured in RPMI supplemented with 10\% FCS and 2 mM L-glutamine. In no case PBMCs, DFs, or LCLs were obtained from the same individual.

\section{ACS affected patients}

In all, 130 elderly consecutive patients (76 males and 54 females), aged from 65 to 99 years (males: mean age $80 \pm 7$ years; females: mean age $79 \pm 7$ years), were diagnosed for ACS. According to ACS diagnostic guidelines, ${ }^{46}$ this syndrome comprehends Q-wave-Myocardial Infarction (Qw-MI), non-Q wave-Myocardial Infarction (NQw-MI), and Unstable Angina (UA). ACS is diagnosed when two of the following criteria are satisfied: (1) clinical presentation (chest pain, epigastric pain, or nontypical symptoms (persistent shortness of breath, unexplained weakness, syncope, or a combination of these); (2) specific ECG modifications: ST-segment elevation $\geqslant 0.1 \mathrm{mV}$ and $>0.2 \mathrm{mV}$ in other leads; STsegment depression or T-wave inversion $\geqslant 0.1 \mathrm{mV}$; and (3) alterations in biochemical markers: myocardium-specific Troponin $>0.05 \mathrm{ng} / \mathrm{ml}$, MB fraction of creatine kinase $(\mathrm{CK}-\mathrm{MB})>10 \mathrm{ng} / \mathrm{ml}$. In particular, patients are classified as NQw-Ml and Qw-Ml, if they present ECG and biochemical markers alterations (CK-MB $>2$ times the upper limit of normality), and UA if they present clinical symptoms and alterations in ECG but not in biochemical markers. At the time of Coronary Care Unit (CCU) admission, we evaluated total and high-density lipoprotein (HDL) cholesterol levels in all patients. The determination of ischaemia markers, such as CK-MB fraction of creatine kinase and Troponin I, was documented on CCU admission and after 6,12 , and $24 \mathrm{~h}$. Data about risk factors for ACS were collected (presence of diabetes, smoking habits, hypertension, hypercholesterolaemia). Standard biochemical parameters, as well as serum folate, vitamin $B_{12}$, homocysteine, $C$-reactive protein were also available for all the patients (evaluated $24 \mathrm{~h}$ after CCU admission) and were used as covariates in Multiple Regression analysis. All subjects gave their informed consent after admission to the CCU (INRCA, Ancona, Italy).

\section{P53 codon 72 genotype assessment}

PBMCs, DFs, and LCLs were obtained from subjects whose p53 codon 72 genotype had been previously assessed on DNA extracted according to standard procedures from frozen whole leucocytes aliquots. ${ }^{33}$ The p53 codon 72 genotype was confirmed in all the cultured cells (DFs and LCLs) by PCR amplification of the p53 exon 4 (5'-GCAGAGACCTGTGGGAAGCGA-3' and 5'-ACCGTAGCTGCCCTGGTAGGT-3') followed by Automatic sequencing in a CEQ2000 Automatic Sequencer (Beckman, Fullerton, CA, USA). The p53 codon 72 polymorphism in ACS patients was assessed on DNA extracted according to standard procedures from frozen whole leucocytes aliquots. p53 codon 72 alleles were amplified using the primers pair indicated above. PCR cycling conditions were as follows: $1 \mathrm{~min}$ at $94^{\circ} \mathrm{C}, 1 \mathrm{~min}$ at $65^{\circ} \mathrm{C}$, and $1 \mathrm{~min}$ at $72^{\circ} \mathrm{C}$, for 28 cycles. The protocol was also carried out for 30 cycles. In total, $15 \mu$ of PCR products were digested with BstUl restriction enzyme (New England Biolabs, Inc., Beverly, MA, USA) as recommended by the supplier, and fragments were separated on $2 \%$ agarose gel. The arginine allele was identified by the presence of the restriction BstUl enzyme recognition sites.

\section{Treatment of DFs, PBMCs, and LCLs with dRib}

The reducing sugar dRib (Sigma, St Louis, MO, USA) was used to elicit oxidative stress-induced apoptosis. ${ }^{23,24}$ dRib exposure time length, and dRib concentrations ( $20 \mathrm{mM}$ for DFs cultures, $10 \mathrm{mM}$ for PBMCs, $10 \mathrm{mM}$ for LCLs) were chosen on the basis of previous data (Kletsas et al.., ${ }^{23}$ Barbieri et al., ${ }^{24}$ and preliminary experiments, data not shown). Under the above-described culture conditions, PBMCs are in a quiescent state. ${ }^{24}$ With respect to DFs, cultures were allowed to reach confluence, medium was changed, and cells were cultivated for at least 3 days in medium containing $0.5 \%$ FCS, prior to being exposed to $20 \mathrm{mM}$ dRib treatment. This procedure does not elicit apoptosis in DFs but rather it leads to an accumulation of cells in the late G1 phase. ${ }^{23}$ DFs were then reseeded at low density $\left(60000 / \mathrm{cm}^{2}\right)$ in FCS-supplemented medium in the presence or absence of $20 \mathrm{mM}$ dRib and assayed for apoptosis at 48 and $72 \mathrm{~h}$. Note that cells were allowed to attach to the plastic substrate before dRib exposure. LCLs were plated at a density of $2 \times 10^{5}$ cells $/ \mathrm{ml}$ in RPMI $10 \% \mathrm{FCS}$, and incubated with $\mathrm{dRib}$ for $24 \mathrm{~h}$.

\section{Expression vectors}

The amplified p53 full-length cDNA fragment was cloned in TOPO TA ${ }^{\mathrm{TM}}$ vector (Invitrogen). The EcoRI-excised fragment was subcloned into a pCMS-EGFP or in a pTRE2Pur plasmid (Clontech, Palo Alto, CA, USA). The entire insert was sequenced to assess the exact orientation and the absence of any sequence variation from the $p 53$ wild-type sequence, by using the following primers pairs: F1:5'-GCCATGGAGGAGCCGCAGTC3', R1:5'-AAGGGACAGAAG ATGACAGG-3'; F2:5'-GCACCAGCAGCTCCTACACC-3', R2:5'-CCACTCGGATAAGAT GCTGA-3'; 
F3:5'-GCCCCTCCTCAGCATCTTAT-3'， R3:5'-AGGAGCTGGTGTTGTTGGGC-3', in a Beckman CEQ2000 automatic sequencer. The arginine/proline variants were also obtained by site-directed mutagenesis (Gene Editor ${ }^{\mathrm{TM}}$, Promega, Madison, CA, USA) using primers ARG-MT: $5^{\prime}$ GAGGCTGCTCCCCGCGTGGCCCCTGCACC-3' or PRO-MT: 5'-GAGGCTGCTCC CCCCGTGGCCCCTGCACC-3'. As expected, no difference was found between experiments performed with p53 codon 72 alleles obtained from homozygous subjects and those obtained by in vitro mutagenesis (data not shown)

\section{Transfection assays}

p53-null SaOs2 cells were cultured in DMEM 10\% FCS. SaOs2 cells were seeded in six-well plates at a concentration of $\left(2 \times 10^{5}\right.$ per plate $)$, and after $24 \mathrm{~h}$ were transiently transfected with $1 \mu \mathrm{g}$ of pCMS-EGFP, either empty, or carrying the p53 arginine (pCMS-p53Arg) or proline (pCMSp53Pro) allele, using the Effectene system, according to the manufacturer's instructions (Qiagen, Valencia, CA, USA). After $24 \mathrm{~h}$, cells were collected and lysed to be assayed by Western blot.

SaOs2 pTet-On cells were obtained by transfecting cells with $1 \mu \mathrm{g}$ of pTet-On ${ }^{\mathrm{TM}}$ plasmid (Clontech) using the Effectene system (Qiagen) and kept in the presence of increasing concentrations (from 100 to $600 \mu \mathrm{g} / \mathrm{ml}$ ) of G418 (Sigma, St Louis, MO, USA) for 4 weeks. G418 resistant stably transfected cells were then employed for transient transfection assay, using pTRE2Pur plasmid, either empty, or carrying the p53 arginine (pTRE-p53Arg) or proline (pTRE-p53Pro) allele. A total of $1 \times 10^{5}$ pTetOn stably transfected cells were seeded in six wells plated and were transfected with $1 \mu \mathrm{g}$ of either PTRE plasmid for $24 \mathrm{~h}$ and exposed to increasing doses of doxycycline $(0.1-1 \mu \mathrm{g} / \mathrm{ml})$ for 48 and then lysed for Western blot assay.

\section{Cytofluorimetric analysis of cell death and mitochondrial potential}

All the cytofluorimetric analyses were performed using a FACScalibur cytometer (BD, San José, CA, USA) equipped with an Argon ion laser tuned at $488 \mathrm{~nm}$. In all analyses, a minimum of 10000 cells per sample were acquired in the list mode and analysed with Cell Quest software.

The DNA content in DFs, PBMCs, LCLs, and p53CMS-p53Arg/Pro transfected SaOs2 cells was assessed using propidium iodide $(\mathrm{PI})$ staining. The appearance of a hypodiploid peak of PI fluorescence was taken as an index of apoptosis in DFs, PBMCs, and LCLs. Briefly, cells were resuspended in hypotonic solution containing $0.1 \%$ sodium citrate, $0.1 \%$ Triton X-100, and $50 \mu \mathrm{g} / \mathrm{ml} \mathrm{PI} \mathrm{(Sigma),} \mathrm{and} \mathrm{kept} \mathrm{for} \mathrm{at} \mathrm{least} 1$ hat $4^{\circ} \mathrm{C}$. Therefore, cells underwent FACS analysis, and those with low $\mathrm{PI}$ fluorescence were considered apoptotic. With respect to SaOs2 cells, cells with low PI fluorescence were considered apoptotic only when also positive for green fluorescence due to GFP-expression. Inasmuch as it is known that cells detached from the culture substrate display the characteristics of cells dying by apoptosis, the number of DFs was taken as an additional index of apoptosis. Culture supernatants were centrifuged at $350 \times g$ for $10 \mathrm{~min}$, and cell pellets were resuspended in $300 \mu \mathrm{l}$ of PBS, then passed through the flow cytometer at low speed. Each sample was allowed to run for $30 \mathrm{~s}$ after flow stabilisation. Considering that FACScalibur sips $12 \mu \mathrm{l}$ per minute at low speed, it is easy to calculate the number of cells that was present in the sample applying the formula: (number of cells counted in $30 \mathrm{~s} / 6 \mu \mathrm{l}) \times 300$. Mitochondrial membrane potential loss $\left(\Delta \Psi^{\mathrm{dim}}\right)$ was evaluated by using the potentiometric probe JC-1 (Molecular Probes, Eugene, OR, USA), which changes reversibly its fluorescent emission from red/orange to green as $\Delta \psi$ decreases (over values of about $80-100 \mathrm{mV}$ ). Briefly, PBMCs were stained with $2.5 \mu \mathrm{g} / \mathrm{ml}$ JC-1 and kept at room temperature for 20 min, washed twice with PBS, resuspended in a total volume of $400 \mu \mathrm{l}$ PBS, and examined by FACS analysis. $^{47}$

\section{Western blot assay and co-immunoprecipitation assay}

Whole-cell lysates for Western blot were obtained from DFs cultured in the presence or absence of $20 \mathrm{mM} \mathrm{dRib}$ for $48 \mathrm{~h}$, from LCLs cultured in the presence or absence of $10 \mathrm{mM} \mathrm{dRib}$ for $24 \mathrm{~h}$, and from SaOs2 transfected cells. Cells were lysed in RIPA Buffer (1\% Triton $x-100,50 \mathrm{mM}$ Tris- $\mathrm{HCl}$ (pH 8.0), $10 \mathrm{mM}$ Tris-HCl (pH 7.5), $150 \mathrm{mM} \mathrm{NaCl}, 5 \mathrm{mM}$ EDTA (pH 8.0), added of protease inhibitor cocktail (Sigma) and $1 \mathrm{mM} \mathrm{NaVO}_{4}$. To obtain whole-cell lysate for co-immunoprecipitation assay, DFs and SaOs2 were lysed in CO-IP Buffer (0.5\% NP-40, $50 \mathrm{mM}$ Tris- $\mathrm{HCl}$ (pH 8.0), $10 \mathrm{mM}$ Tris$\mathrm{HCl}(\mathrm{pH} 7.5), 150 \mathrm{mM} \mathrm{NaCl}, 5 \mathrm{mM}$ EDTA (pH 8.0), with addition of protease inhibitor cocktail (Sigma), and $1 \mathrm{mM} \mathrm{NaVO}_{4}$. Co-immunoprecipitation assay was performed as follows: after triplicate quantisation with Bradford assay, $200 \mu \mathrm{g}$ of proteins were washed with Protein A Sepharose-conjugated beads (Santa Cruz Biotechnology, Santa Cruz, CA, USA), incubated with anti p53 antibodies ( $1 \mu \mathrm{g} \mathrm{DO}-1$ and $1 \mu \mathrm{g}$ of pAb421) at $4^{\circ} \mathrm{C}$ overnight in extensive shaking, washed four times with cold CO-IP buffer, and incubated for $2 \mathrm{~h}$ with Protein A Sepharoseconjugated beads. The obtained pellet was resuspended in Laemly buffer and directly loaded onto polyacrylamide gel. For Western blot analysis, $30 \mu \mathrm{g}$ of whole-cell lysates were loaded for each lane. The antibodies used were: anti-Poly(ADP-ribose) polymerase (PARP) (BIOMOL Research Laboratories, Plymouth, PA, USA), anti-p53 (DO-I), anti- $\beta$ tubulin $(\mathrm{H}-$ 2359), anti-MDM2 (SMP-14), anti-Bcl-xL (S-18), anti-Bax alpha (clone B9), anti-p21WAF1 (C-19), anti-actin, anti-tubulin (Santa Cruz Biotechnologies, Santa Cruz, CA, USA), anti-Serine 15 phosphorylated p53 (Oncogene Research Products, San Diego, CA, USA), anti-Caspase 3 (Cell Signalling Technology, MA, USA and Biomol, Plymouth Meeting, PA, USA), and anti-EGFP (Clontech, CA, USA). All primary antibodies were probed by a secondary Horse Radish Peroxidase (HRP) conjugated antibody (Bio-Rad). Chemiluminescent assay was used for detection (Santa Cruz). Gel imaging was performed using a GelDoc 2000 (Bio-Rad Laboratories, Inc., Hercules, CA, USA) acquisition system and Quantity One 4.1.1 software (Bio-Rad).

\section{Fluorescence microscopy}

DFs were cultured on plastic chamber slides Lab Tek II (Nalge Nunc, Naperville, IL, USA) and treated with or without $20 \mathrm{mM}$ dRib for $48 \mathrm{~h}$, then fixed with $4 \%$ paraformaldehyde in PBS for $10 \mathrm{~min}$, then permeabilised with $0.1 \%$ Triton X-100 and stained for nucleic acid with $5 \mu \mathrm{g} / \mathrm{ml}$ Hoechst 33258 stain (Sigma), and mounted with ProLong antifade (Molecular Probes). Slides were then observed with an Orthoplan fluorescent microscope (Leitz, Bielefeld, Germany) with $\times 60$ oil-immersion magnification. Images were collected with a Kodak image analysis system and analysed with Thumbs Plus 5 software (Cerious Software, Charlotte, NC, USA). For experiments of p53 localisation, DFs were incubated with $20 \mathrm{mM} d R i b$ for $48 \mathrm{~h}$ or with $500 \mu \mathrm{M} \mathrm{H} \mathrm{O}_{2}$ for $2 \mathrm{~h}$, then stained with $80 \mathrm{nM}$ MitoTracker Red CMXRos (Molecular Probes) $45 \mathrm{~min}$ before the end of $\mathrm{dRib}$ incubation, fixed as described above and stained according to standard protocols for intracellular antigens with monoclonal antibodies against p53 (clone D0-1, Santa Cruz) revealed by 
a FITC-conjugated secondary antibody (BD). Exposure time and fluorescence enhancement were fixed at a value by which green and red fluorescences were undetectable in unstained samples.

\section{Statistical analysis}

GLM ANOVA, Multiple Regression analysis, and Fisher's exact test were used to test for differences in quantitative variables, which were log transformed when required. Fisher's Exact test was performed in categorical variables. Data analysis was performed by SPSS 10 Package (SPSS, Chicago, IL, USA).

\section{Acknowledgements}

This work was supported by AIRC (Associazione Italiana Ricerca sul Cancro) Grant, EU (European Union) Grants 'FUNCTIONAGE', 'ECHA', 'T-CIA', and ex 40\% MIUR, (Italian Ministry of University) Grant, and FIRB (Fondi Istituzionali per la Ricerca di Base) and Ministero della Salute (Italian Ministry of Health) Finalizzate 2003 Grant to CF.

\section{References}

1. Hwang PM, Bunz F, Yu J, Rago C, Chan TA, Murphy MP, Kelso GF, Smith RA, Kinzler KW and Vogelstein B (2001) Ferredoxin reductase affects p53dependent, 5-fluorouracil-induced apoptosis in colorectal cancer cells. Nat. Med. 7: 1111-1117

2. Sansome C, Zaika A, Marchenko ND and Moll UM (2001) Hypoxia death stimulus induces translocation of p53 protein to mitochondria. Detection by immunofluorescence on whole cells. FEBS Lett. 488: 110-115

3. Fiordaliso F, Leri A, Cesselli D, Limana F, Safai B, Nadal-Ginard B, Anversa P and Kajstura J (2001) Hyperglycemia activates p53 and p53-regulated genes leading to myocyte cell death. Diabetes 50: 2363-2375

4. Kaneto H, Fujii J, Myint T, Miyazawa N, Islam KN, Kawasaki Y, Suzuki K, Nakamura M, Tatsumi H, Yamasaki Y and Taniguchi N (1996) Reducing sugars trigger oxidative modification and apoptosis in pancreatic beta-cells by provoking oxidative stress through the glycation reaction. Biochem. J. 320 : 855-863

5. Finkel T and Holbrook NJ (2000) Oxidants, oxidative stress and the biology of ageing. Nature 408: 239-247

6. Kim H, Lee DK, Choi JW, Kim JS, Park SC and Youn HD (2002) Analysis of the effect of aging on the response to hypoxia by cDNA microarray. Mech. Ageing Dev. 124: 941-949

7. Robertson RP, Harmon J, Tran PO, Tanaka Y and Takahashi H (2003) Glucose toxicity in beta-cells: type 2 diabetes, good radicals gone bad, and the glutathione connection. Diabetes 52: 581-587

8. Migliaccio E, Giorgio M, Mele S, Pelicci G, Reboldi P, Pandolfi PP, Lanfrancone $L$ and Pelicci PG (1999) The p66shc adaptor protein controls oxidative stress response and life span in mammals. Nature 402: 309-413

9. Napoli C, Martin-Padura I, de Nigris F, Giorgio M, Mansueto G, Somma P, Condorelli M, Sica G, De Rosa G and Pelicci P (2003) Deletion of the p66Shc longevity gene reduces systemic and tissue oxidative stress, vascular cell apoptosis, and early atherogenesis in mice fed a high-fat diet. Proc. Natl. Acad. Sci. USA 100: 2112-2116

10. Trinei M, Giorgio M, Cicalese A, Barozzi S, Ventura A, Migliaccio E, Milia E, Padura IM, Raker VA, Maccarana M, Petronilli V, Minucci S, Bernardi P, Lanfrancone $L$ and Pelicci PG (2002) A p53-p66Shc signalling pathway controls intracellular redox status, levels of oxidation-damaged DNA and oxidative stress-induced apoptosis. Oncogene 21: 3872-3878

11. de Nigris F, Lerman LO, Ignarro SW, Sica G, Lerman A, Palinski W, Ignarro LJ and Napoli C (2003) Beneficial effects of antioxidants and L-arginine on oxidation-sensitive gene expression and endothelial NO synthase activity at sites of disturbed shear stress. Proc. Natl. Acad. Sci. USA 100: 1420-1425

12. Hofseth LJ, Saito S, Hussain SP, Espey MG, Miranda KM, Araki Y, Jhappan C, Higashimoto Y, He P, Linke SP, Quezado MM, Zurer I, Rotter V, Wink DA,
Appella E and Harris CC (2003) Nitric oxide-induced cellular stress and p53 activation in chronic inflammation. Proc. Natl. Acad. Sci. USA 100: 143-148

13. Guevara NV, Kim HS, Antonova El and Chan L (1999) The absence of p53 accelerates atherosclerosis by increasing cell proliferation in vivo. Nat. Med. 5 : 335-339

14. Mnjoyan ZH, Dutta R, Zhang D, Teng BB and Fujise K (2003) Paradoxical upregulation of tumor suppressor protein p53 in serum-stimulated vascular smooth muscle cells. A novel negative-feedback regulatory mechanism. Circulation 108: 464-471

15. Monti D, Salvioli S, Capri M, Malorni W, Straface E, Cossarizza A, Botti B, Piacentini M, Baggio G, Barbi C, Valensin S, Bonafè M and Franceschi $C$ (2000) Decreased susceptibility to oxidative stress-induced apoptosis of peripheral blood mononuclear cells from healthy elderly and centenarians. Mech. Ageing Dev. 121: 239-250

16. Schindowski K, Leutner S, Muller WE and Eckert A (2000) Age-related changes of apoptotic cell death in human lymphocytes. Neurobiol. Aging 21: 661-670

17. Dumont $P$, Leu JIJ, Della Pietra III AC, Donna LG and Maureen M (2003) The codon 72 polymorphic variants of p53 demonstrate significant differences in apoptotic potential. Nat. Genet. 33: 357-365

18. Thomas M, Kalita A, Labrecque S, Pim D, Banks L and Matlashewski G (1999) Two polymorphic variants of wild-type p53 differ biochemically and biologically. Mol. Cell. Biol. 19: 1092-1100

19. Storey A, Thomas M, Kalita A, Harwood C, Gardiol D, Mantovani F, Breuer J, Leigh IM, Matlashewski $G$ and Banks L (1998) Role of a p53 polymorphism in the development of human papillomavirus-associated cancer. Nature 393: 229-234

20. Marin MC, Jost CA, Brooks LA, Irwin MS, O'Nions J, Tidy JA, James N, McGregor JM, Harwood CA, Yulug IG, Vousden KH, Allday MJ, Gusterson B, Ikawa S, Hinds PW, Crook T and Kaelin Jr WG (2000) A common polymorphism acts as an intragenic modifier of mutant p53 behaviour. Nat. Genet. 25: 47-54

21. Franceschi C, Motta L, Valensin S, Rapisarda R, Franzone A, Berardelli M, Motta M, Monti D, Bonafe M, Ferrucci L, Deiana L, Pes GM, Carru C, Desole MS, Barbi C, Sartoni G, Gemelli C, Lescai F, Olivieri F, Marchegiani F, Cardelli M, Cavallone L, Gueresi P, Cossarizza A, Troiano L, Pini G, Sansoni P, Passeri G, Lisa R, Spazzafumo L, Amadio L, Giunta S, Stecconi R, Morresi R, Viticchi C, Mattace R, De Benedictis $G$ and Baggio G (2000) Do men and women follow different trajectories to reach extreme longevity? Italian Multicenter Study on Centenarians (IMUSCE). Aging (Milano) 2: 77-84

22. Franceschi $C$ and Bonafe $M$ (2003) Centenarians as a model for healthy aging Biochem. Soc. Trans. 31: 457-461

23. Kletsas D, Barbieri D, Stathakos D, Botti B, Bergamini S, Tomasi A, Monti D, Malorni $W$ and Franceschi $C$ (1998) The highly reducing sugar 2-deoxy-Dribose induces apoptosis in human fibroblasts by reduced glutathione depletion and cytoskeletal disruption. Biochem. Biophys. Res. Commun. 243: 416-425

24. Barbieri D, Grassilli E, Monti D, Salvioli S, Franceschini MG, Franchini A, Bellesia E, Salomoni P, Negro P and Capri M (1994) D-ribose and 2-deoxy-Dribose induce apoptosis in human quiescent peripheral blood mononuclear cells. Biochem. Biophys. Res. Commun. 201: 1109-1116

25. Tanaka Y, Tran PO, Harmon J and Robertson RP (2002) A role for glutathione peroxidase in protecting pancreatic beta cells against oxidative stress in a model of glucose toxicity. Proc. Natl. Acad. Sci. USA 99: 12363-12368

26. Matsuoka $T$, Kajimoto $Y$, Watada $H$, Kaneto $H$, Kishimoto M, Umayahara $Y$, Fujitani Y, Kamada T, Kawamori R and Yamasaki Y (1997) Glycationdependent, reactive oxygen species-mediated suppression of the insulin gene promoter activity in HIT cells. Clin. Invest. 99: 144-150

27. Litchfield JE, Thorpe SR and Baynes JW (1999) Oxygen is not required for the browning and crosslinking of protein by pentoses: relevance to Maillard reactions in vivo. Int. J. Biochem. Cell. Biol. 31: 1297-1305

28. Brown NS and Bicknell R (1998) Thymidine phosphorylase, 2-deoxy-D-ribose and angiogenesis. Biochem. J. 334: 1-8

29. Brown NS and Bicknell R (2001) Hypoxia and oxidative stress in breast cancer. Oxidative stress: its effects on the growth, metastatic potential and response to therapy of breast cancer. Breast Cancer Res. 3: 323-327

30. Focher F and Spadari S (2001) Thymidine phosphorylase: a two-face Janus in anticancer chemotherapy. Curr. Cancer Drug Targets 1: 141-153 
31. Ignatescu MC, Gharehbaghi-Schnell E, Hassan A, Rezaie-Majd S, Korschineck I, Schleef RR, Glogar HD and Lang IM (1999) Expression of the angiogenic protein, platelet-derived endothelial cell growth factor, in coronary atherosclerotic plaques: in vivo correlation of lesional microvessel density and constrictive vascular remodeling. Arterioscler. Thromb. Vasc. Biol. 19: 2340-2347

32. Boyle JJ, Wilson B, Bicknell R, Harrower S, Weissberg PL and Fan TP (2000) Expression of angiogenic factor thymidine phosphorylase and angiogenesis in human atherosclerosis. J. Pathol. 192: 234-242

33. Bonafe M, Olivieri F, Mari D, Baggio G, Mattace R, Berardelli M, Sansoni $P$, De Benedictis G, De Luca M, Marchegiani F, Cavallone L, Cardelli M, Giovagnetti S, Ferrucci L, Amadio L, Lisa R, Tucci MG, Troiano L, Pini G, Gueresi P, Morellini M, Sorbi S, Passeri G, Barbi C and Valensin S (1999) p53 codon 72 polymorphism and longevity: additional data on centenarians from continental Italy and Sardinia. Am. J. Hum. Genet. 65: 1782-1785

34. Bonafè M, Barbi C, Storci G, Salvioli S, Capri M, Olivieri F, Valensin S, Monti D, Gonos E, De Benedictis G and Franceschi C (2002) What studies on human longevity tell us about the risk for cancer in the oldest old: data and hypotheses on the genetics and immunology of centenarians. Exp. Gerontol. 37: 1263-1271

35. Berger M, Vogt Sionov R, Levine AJ and Haupt Y (2001) A role for the polyproline domain of p53 in its regulation by Mdm2. J. Biol. Chem. 276: 3785-3790

36. Mihara M, Erster S, Zaika A, Petrenko O, Chittenden T, Pancoska P and Moll UM (2003) p53 has a direct apoptogenic role at the mitochondria. Mol Cell Mar 11: $577-590$

37. Regula KM and Kirshenbaum LA (2001) p53 activates the mitochondrial death pathway and apoptosis of ventricular myocytes independent of de novo gene transcription. J. Mol. Cell Cardiol. 33: 1435-1445

38. Mair J (1997) Progress in myocardial damage detection: new biochemical markers for clinicians. Crit. Rev. Clin. Lab. Sci. 34: 1-66
39. Wu X, Zhao H, Amos Cl, Shete S, Makan N, Hong WK, Kadlubar FF and Spitz MR (2002) p53 genotypes and haplotypes associated with lung cancer susceptibility and ethnicity. J. Natl. Cancer Inst. 94: 681-690

40. Biros E, Kohut A, Biros I, Kalina I, Bogyiova E and Stubna J (2002) A link between the p53 germ line polymorphisms and white blood cells apoptosis in lung cancer patients. Lung Cancer 35: 231-235

41. Saito S, Yamaguchi H, Higashimoto Y, Chao C, Xu Y, Fornace Jr AJ, Appella E and Anderson CW (2003) Phosphorylation site interdependence of human p53 post-translational modifications in response to stress. J. Biol. Chem. 278: 37536-37544

42. Levraut J, Iwase H, Shao ZH, Vanden Hoek TL and Shumacker PT (2003) Cell death during ischemia: relationship to mitochondrial depolarization and ROS generation. Am. J. Physiol. Heart Circ. Physiol. 284: H549-H558

43. Hofstra L, Liem IH, Dumont EA, Boersma HH, van Heerde WL, Doevendans $P A$, De Muinck E, Wellens HJ, Kemerink GJ, Reutelingsperger $\mathrm{CP}$ and Heidendal GA (2000) Visualisation of cell death in vivo in patients with acute myocardial infarction. Lancet 356: 209-212

44. Kim JS, He L and Lemasters JJ (2003) Mitochondrial permeability transition: a common pathway to necrosis and apoptosis. Biochem. Biophys. Res. Commun. 304: 463-470

45. Leri A, Franco S, Zacheo A, Barlucchi L, Chimenti S, Limana F, Nadal-Ginard B, Kajstura J, Anversa P and Blasco MA (2003) Ablation of telomerase and telomere loss leads to cardiac dilatation and heart failure associated with p53 upregulation. EMBO J. 22: 131-139

46. Alpert JS, Thygesen K, Antman E and Bassand JP (2000) Myocardial infarction redefined-a consensus document of the joint European Society of Cardiology/ American College of Cardiology Committee for the redefinition of myocardial infarction. J. Am. Coll. Cardiol. 36: 959-9569

47. Salvioli S, Ardizzoni A, Franceschi C and Cossarizza A (1997) JC-1, but not $\mathrm{DiOC}_{6}(3)$ or rhodamine 123 , is a reliable fluorescent probe to assess delta psi changes in intact cells: implications for studies on mitochondrial functionality during apoptosis. FEBS Lett. 411: 77-82 